spread as widely as possible among the armed forces and the population in general.

Resolution No. 6.-To recommend that National Societies approach their respective governments to obtain authorization for the use of the radio frequencies allocated to the ICRC by the International Telecommunications Union.

Resolution No. 7.-To recommend that the National Societies of the region obtain radio equipment through the ICRC as soon as possible in order that, by using the frequencies allocated to the ICRC by the ITU, they may establish permanent contact with one another and, through the ICRC regional delegation, with the international Red Cross organizations in Geneva.

Resolution No. 11.-To recommend:

(1) that each National Society be obliged to supervise the use of the emblem;

(2) that all National Societies examine any abuses occurring in their respective countries and forward their findings to the ICRC and League delegates so that steps may be taken to have such abuses curbed by the government authorities;

(3) that in so far as is possible all emblems be changed to comply with the specifications laid down.

\title{
MEETING IN BAGHDAD OF THE ARAB RED CRESCENT AND RED CROSS SOCIETIES
}

From 5 to 9 March 1972, the Fifth Meeting of Arab Red Crescent and Red Cross Societies in Baghdad was attended by some ten National Societies. The League of Red Cross Societies and the International Committee of the Red Cross having been invited to send observers, the League was represented by Mr. H. Beer, Secretary-General, Mr. A. Rörholt, Director, and Mr. Y. Kiamouche, Head of the Regional Service for North Africa and the Near East, 


\section{IN THE Red CROSS WORLD}

and the Committee by Mr. J.-P. Maunoir, Assistant Director, Mr. A. Modoux, Head of Press and Information Division, and Mr. A. Martin, Legal Adviser.

After being opened by Dr. Izzat Mustafa, Iraqi Minister of Health and President of the Iraqi Red Crescent, the Conference elected as its chairman Mr. Sabih Al Wa'bi, the former President of the Iraqi Red Crescent.

The agenda included some items which had been broached at earlier meetings, the examination of action taken to follow up recommendations adopted at the 1971 meeting in Beirut, relations between the ICRC and the National Societies directly concerned in the Middle East conflict, co-operation among Arab National Societies and co-ordination of their objectives on the various League committees. Discussion also took place on work undertaken in connection with international humanitarian law, in the light of the recent Vienna conference of Red Cross Experts and of that of Government Experts which is to be held in Geneva. Another subject dealt with was recognized National Society assistance to Red Crescent Societies in the process of formation.

The wish was expressed for the wider use of Arabic in the Red Cross and Red Crescent world, particularly for the dissemination of news.

The meeting adopted a number of recommendations relating to various agenda items, and it was agreed to hold the Sixth Meeting at Amman in 1973. 